\title{
LATIN JOURNEY
}


This page intentionally left blank 


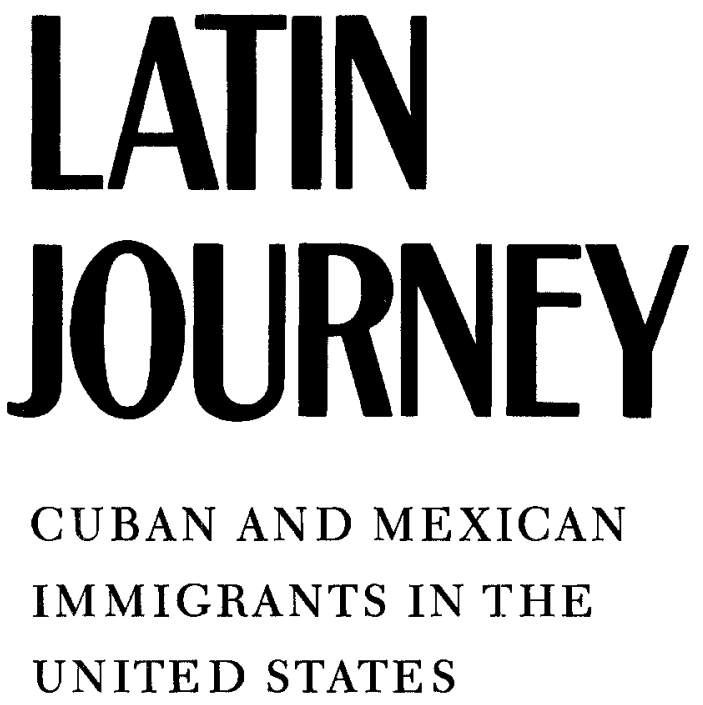

\section{ALEJANDRO PORTES \\ ROBERT L. BACH}

University of California Press

Berkeley - Los Angeles • London 
University of California Press Berkeley and Los Angeles, California

University of California Press, Ltd. London, England

1985 by The Regents of the University of California

Library of Congress Cataloging in Publication Data

Portes, Alejandro, 1944-

Latin journey.

Bibliography: p.

Includes index.

1. Cubans-United States-Economic conditions.

2. Cubans-United States-Social conditions.

3. Mexicans-United States-Economic conditions.

4. Mexicans-United States-Social conditions.

5. United States-Foreign population.

I. Bach, Robert L. II. Title.

E184.C97P67 $1985 \quad 305.8^{\prime 6} 687291^{\prime 073} \quad 83-9292$

ISBN 0-520-05003-7

ISBN 0-520-05004-5 (pbk.)

Printed in the United States of America

This book is a print-on-demand volume. It is manufactured using toner in place of ink. Type and images may be less sharp than the same material seen in traditionally printed University of California Press editions. 
To the Memory of Our Fathers 
This page intentionally left blank 